\title{
MEASURING BRAND EQUITY OF COSMECEUTICALS - A CASE USING CONSUMER BASED BRAND EQUITY MODEL
}

\author{
VAIJAYANTHI P, SHREENIVASAN KA \\ School of Management, SASTRA University, Thanjavur, Tamil Nadu, India. Email: vaijayanthi@mba.sastra.edu
}

Received: 29 March 2016, Revised and Accepted: 16 March 2017

ABSTRACT

Objective: This study intends to operationalize brand equity and form a standard measure of it that could be used across cosmeceutical products to measure brand equity. It attempts to provide an indication of a set of items that can contribute to brand equity.

Methods: A survey instrument containing the said brand equity concept was administered to a sample pool of 200 select beauticians and consumers of a leading Indian Cosmeceutical brand identified using stratified random sampling method, from among the universe of the users of the product in Tiruchirappalli district, Tamil Nadu.

Results: The results obtained confirm that the dimensions, viz., brand awareness, perceived quality, brand loyalty, brand association, and brand image were found to significantly contribute to brand equity in cosmeceutical products. The regression confirms that perceived quality and brand associations are not causal drivers but are only indirect drivers of brand equity. Further, the dimension perceived quality was very strongly related with both brand loyalty and brand image, and brand loyalty was very strongly related with brand association among the beauticians segment of the sample. In the case of the brand equity dimensions among consumers, the brand association was very strongly related with brand awareness, perceived quality, and perceived quality was very strongly associated with the brand image.

Conclusion: The outcomes of the study confirm that cognitive components of perceived quality and brand association were less contributing to brand equity and the affective component of brand loyalty had stronger underpinning on brand equity construction and hence play an important role in brand management. The brand equity structure gives a very good clarification of brand equity drivers and also their relationships, to formulate a cause and effect model. The model can form a basis for more action-based tactical and operational marketing strategies.

Keywords: Brand equity, Customer based approach, Brand equity dimensions, Cosmeceutical brand equity.

(C) 2017 The Authors. Published by Innovare Academic Sciences Pvt Ltd. This is an open access article under the CC BY license (http://creativecommons. org/licenses/by/4. 0/) DOI: http://dx.doi.org/10.22159/ajpcr.2017.v10i6.11921

\section{INTRODUCTION}

For brand equity to provide strategic inputs and aid marketing decisions, it is important to recognize its underlying drivers and their consequences [1]. A five-dimensional scale to capture brand equity consisting of brand loyalty, perceived quality, brand awareness, brand image, and brand association was developed based on the conceptualization of brand equity dimensions by Keller et al., Aaker [2-5]. Cosmeceuticals are cosmetic products that contain therapeutic/medicinal benefits. These products are purchased over the counter without a doctor's prescription. Cosmeceuticals were discovered as a result of convergence involving personal care and pharmaceutical products. The development of technological innovations and the emergence of new ingredients can be held to have spurred the expansion of this market. Cosmeceuticals market has been witnessing significant growth in the Global Personal Care Industry. Thus, the global cosmeceutical market is expected to grow at a CAGR of 9\% during 2015-2020 [6].

In the context of the economies of principal growth markets now starting to compose down, there is mounting pressure on cosmeceutical business to find potential niches for growth in developed markets and to build new positions in the most resilient regions of the emerging markets. With a permutation of underdeveloped consumer markets, growing economies and vast populations with increasing disposable incomes, it is easy to see why cosmeceuticals manufacturers are drawn to producing high quality, innovative and top priced brands.

Brand equity regarded as a key marker of a healthy brand is explored intensively by both researchers and practitioners as a dynamic contributor in effective brand management. Brand equity, referred to as "the incremental utility or value added to a product by its brand name" [4], has been construed as a primary asset for many industries. Hence, monitoring brand equity becomes essential for effective brand management. According to Yoo and Donthu [7], brand equity has substantial positive effects on a company including influence on future profits and long-term cash flow, willingness of consumers to pay premium prices, merger and acquisition decisions, sustainable competitive advantage, and in all, successful marketing. Brand management is also held to play a key role in framing of corporate strategies [8].

Brand name is a cue for recognizing successful brands and is always linked with images that have been shaped by their experiences with a brand [9]. Familiar brands signal trust and are likely to be preferred by consumers who may make a brand judgment solely on brand familiarity. Consumers learn to predict product quality based on brand attribute cues [10]. They tend to develop a sort of association between brand attributes, brand benefits and a brand over time-based 
on direct experiences such as trial or indirect experiences such as advertising [6,2]. Brand building also results in positive benefits such as defending against competitors and building market share [2]. When customers begin to develop a loyalty to a particular brand they buy more, are willing to pay higher prices and generate positive word-ofmouth images about the brands [11-13]. Hence, a better understanding of brand equity measurement is essential for meaningful brand management strategies.

\section{Review of literature}

\section{Brand equity}

A brand described variously as "a set of assets (and liabilities) linked to a brand's name and symbol that adds to (or subtracts from) the value provided by a product or service to a firm and/or a firm's customers" [5]; "the differential effect of the brand knowledge on consumer response to the marketing of the brand" [2]. Similarly, Yoo and Donthu [7], define brand equity as "consumer's differential response between a focal brand and an unbranded product when both have the same level of the marketing stimuli and product attributes." According to Srinivasan et al. [14], brand equity is defined as "the incremental contribution (in money value) per year obtained by the brand in comparison to the underlying product (or service) with no brand-building efforts." It is the added value endowed by the brand name [15] and comprises brand loyalty, brand awareness, perceived quality, brand image, and brand association [16]. According to Morgan's [17] equity engine model of brand equity, there are two classes of equity components - Functional performance and affinity. The former is category specific, while the latter is a set of universal rules for the emotional side of branding.

To summarize the brand equity literature has formulated three main perspectives of brand equity: The financial perspective, the customerbased perspective, and the combined perspective [2]. The "financial brand equity is based on the incremental discounted future cash flows that result from a branded product's revenue over the revenue of an unbranded product. On the other hand, the customer-based brand equity is defined as the differential effect of brand knowledge on a customer's response to the marketing of the brand" [2]. The combined perspective incorporates both financial brand equity and customerbased brand equity.

\section{Measuring brand equity}

Researchers have adopted different approaches to quantify/measure brand equity. Keller [14], Park and Srinivasan [18], and Yoo and Donthu [7] employed perceptual, or psychological measures to gauge brand equity, whereas, Kamakura and Russell [19], used actual consumer and market behavior to compute brand equity. Aaker [5], combined both market behavior-related measures and perceptual measures to outline a framework to measure brand equity.

This study focuses on the customer-based perspective of brand equity, of Aaker [16] and Keller [2]. This model was advocated also by various other researchers. Customer-based brand equity is operationalized into two categories: Consumer perception and customer behavior (like brand loyalty) [7,20-24]. Although many researchers hold customer-based brand equity to include only perceptual dimensions, Aaker's [16] definition of customer-based brand equity includes both perceptual and behavioral dimensions. This broader conceptualization has been widely accepted and employed by many researchers.

Konecnik and Gartner [25] projected a three component model of brand equity - namely, cognitive, affective, and conative. The cognitive component represents an awareness that is associated with what the consumer knows or thinks about a brand. The affective component is built on how one feels about this knowledge. The conative component is the action stage that relates to how one act on the information and how they feel about a brand. Konecnik and Gartner [25] believed that the dimensions of perceived quality and brand image influence the affective component more when attitudes and feelings toward what is known, i.e., brand awareness, are appraised. Brand loyalty, whether attitudinal or behavioral, is pertinent to the conative component.

Collectively, brand equity consists of four dimensions: Brand awareness, perceived quality of brand, brand image (or associations), and brand loyalty $[5,7,16]$. Yoo and Donthu [7] also campaign the use of these dimensions to investigate the findings of marketing and consumer behavior research in relation to brand equity. Thus, both perceptual and behavioral components of brand equity and a causal relationship between perceptual and behavioral dimensions have been advocated. The strength of taking both perceptual and behavioral dimensions into account when measuring brand equity is that the consumer perceptions are clearly an antecedent to behavioral manifestations of brand equity. Although behavioral measures of purchase reveal the existence of equity, they fail to expose the factors actually driving equity without evaluating the perceptual dimension of brand equity [20].

Brand awareness is "the ability for a buyer to recognize or recall that a brand is a member of a certain product category" [16] and it includes both brand recognition and recall [2]. According to Keller [1], brand recognition "is the extent to which a person is able to recognize a particular brand given a set of brands." Brand recall is "the extent to which a person is able to remember a brand, given a product category or need." Aaker [5], exposes various levels of brand awareness. These levels are brand recognition, brand recall, top of mind, brand dominance, brand knowledge, and brand opinion. In this study, the research instrument included questions related to brand opinion and brand knowledge.

Perceived quality is "the consumer's judgment about a product's overall excellence or superiority" [13]. Brand image is "a set of brand association that is anything linked in memory to a brand, usually in some meaningful way" [16]. Leone et al. [26] define them as the associations held in consumer memory based on perceptions of an organization. This study adopts Aaker's conceptualization of brand image.

Brand loyalty is defined as "the attachment that a customer has to a brand" [16]. Brand loyalty plays a significant role in generating brand equity not only because of its capacity to keep a customer loyal, but also because customer's loyalty extends to the other brands in the company's portfolio [27]. Oliver [28] defined loyalty as "an attained state of enduring preference to the point of determined defense." There are two parts in this definition: One is the enduring preference and the other is the point of determined defense. Enduring preference indicates that purchase of the product is repeated again and again, and "the point of determined defense" means that the consumer defends himself from the aggression of competitors. Mellens et al. [29] refer to brand loyalty as "the biased behavioral response expressed over time by some decision-making a unit with respect to one or more alternative brands out of a set of such brands and is a function of psychological processes." Although conventionally, loyalty is a component of brand equity [16], others argue that loyalty is an outcome of brand equity [30] and it may have a positive influence on the customer's willingness to repurchase and recommend the brand [31]. Brand loyalty is seen as a component of brand equity by both traditional researchers [16] and contemporary scholars $[31,32]$. Whereas some studies confirm loyalty as an outcome of brand equity $[30,33]$.

There exists a general misinterpretation between the terms brand identity and brand image. Kapferer [34] maintains that brand identity is brand management perspective because, unlike brand image, it is created by the brand owner. Aaker and Joachimsthaler [35] also reinstate the significance of brand identity. Aaker clarifies brand identity as "a unique set of brand associations that the brand strategist aspires to create or maintain." To a consumer, these associations signify what the brand stands for and involves a promise that the customer can expect from the organization. Aaker classifies three types of 
brand associations when conversing on measures for brand equity. The three types of associations are the brand as a product, brand as an organization and brand as a personality. This study has considered the associations related to the product in the form of perceived value associations, and associations related to organization, when framing the questionnaire.

\section{Purpose of the study}

This study intends to operationalize brand equity and form a standard measure of it that could be used across cosmeceutical products to measure brand equity. It attempts to provide an indication to a set of items that can contribute to brand equity so as to confirm a combination of these items to capture and explain brand equity. But whether these items are exhaustive have not been verified. Based on the dimensions depicted by Keller [12] and Aaker [5] a multidimensional scale to measure brand equity has been developed. The scale consisted of brand loyalty, perceived quality, brand awareness, brand image, and brand associations as different dimensions to capture brand equity.

\section{METHODS}

\section{Instruments and measurements}

The constructs of brand equity dimensions $[2,16]$ and its impact on brand equity were conceptualized and operationalized using a 5-point Likert scale in the survey instrument. The overall Cronbach's alpha score of 0.904 indicates a very good reliability of the instrument used for the study.

Brand equity was measured using the weighted average method from the scores obtained from the five dimensions of measuring customer-based brand equity. Hypothesis testing with regard to the interrelationship of the dimensions of brand equity was analyzed, and an intercorrelation matrix was computed. Multi-stage regression applications have also been used to confirm the relationships.

\section{Survey data and sample}

The sample pool consisted of the selected 200 beauticians and consumers of a leading cosmeceutical brand using stratified random sampling method from among the universe of the users of the product in Tiruchirappalli, Tamil Nadu. Since the cosmetic products are unique in that, they have an ultimate consuming group and another intermediary group (Beauticians), both the groups were considered for the study. A five-dimensional scale to capture brand equity consisting of brand loyalty, perceived quality, brand awareness, brand image, and brand association was developed based on the conceptualization of these dimensions by Keller [2-4], and Aaker [5]. The questionnaire was designed based on literature reviewed was used as the survey instrument including all the constructs, which were operationalized using a 5-point Likert scale. Some questions conceptualizing composite brand equity were also included.

\section{Statistical tools}

Collected data were analyzed with tools such as percentage analysis, correlation, weighted average computations of brand equity score. Correlations and regressions were used to confirm the component and consequential drivers of brand equity, respectively.

\section{RESULTS AND DISCUSSION}

The brand equity score computed using the average scores of the five major dimensions of brand equity worked to 2.27 for the customers and less than that (2.08) for the beauticians (Table 1).

Table 1: Brand equity score

\begin{tabular}{lll}
\hline Score & Beauticians & Consumers \\
\hline Brand equity score & 2.0877 & 2.2705 \\
\hline
\end{tabular}

The descriptive statistics of the brand equity dimensions have been presented in Table 2. On a five-point scale, the item scores for the dimensions of brand equity were all very low (most of them less than the midpoint of 2.5). The overall scores for all the five dimensions were also very low, indicating very low brand performance, although these scores were relatively higher among the customers than among the beauticians.

Further, various indirect relationships among the brand equity dimensions were observed.

The inter-correlation scores obtained (Table 3) support the following hypotheses:

Based on the results obtained in Table 4, all the five dimensions, viz., brand awareness, perceived quality, brand loyalty, brand association, and brand image were found to significantly contribute to brand equity in both groups. A further analysis of the correlations obtained for tactical marketing decisions, reveals that perceived quality was very strongly related with both brand loyalty and brand image ( 0.920 and 0.837 , respectively), and brand loyalty was very strongly related with brand association (0.874) among the beauticians group. In the case of the brand equity dimensions among consumers, brand association was very strongly related with brand awareness, perceived quality ( 0.824 and 0.802 , respectively), and perceived quality was very strongly associated with brand image (0.769).

Further, the factor scores of brand awareness, brand loyalty, perceived quality, brand association, and brand image were used as an independent variable and regressed with brand equity as a dependent variable.

It is confirmed (from Table 5) that the coefficient of brand awareness, brand loyalty, and brand image is significant, while the coefficients of perceived quality and brand association were insignificant.

The possibility that brand loyalty would play a mediating role between perceived quality and brand equity needed to be verified. Similarly, the role of brand image as a mediator between brand association and brand equity should be verified.

\section{Brand loyalty and brand image as mediators}

Two separate regressions were run to check the mediating role of brand loyalty and brand image. The results of these regressions are shown in Tables 6 and 7. The results prove the mediating role of brand loyalty between perceived quality and brand equity (significant 0.000), and brand image between brand association and brand equity (significant 0.000 ). Thus, the outputs confirm that perceived quality and brand association do not have a direct impact on brand equity, but only an indirect impact, through brand loyalty and brand image.

Thus, the regressions confirm that perceived quality and brand associations are not causal drivers of brand equity as projected by Keller [2] and Aaker [16] but are only indirect drivers.

\section{CONCLUSION}

\section{Implications for practice}

A considerable proportion of the consumer respondents has shown conspicuous strong feelings about the brands they patronize. In an industry with abundant choices and very low switching costs, these mindsets/outlook can transform into valuable brand loyalty, higher levels of spending, and also the person-to-person promotion of the brand to others. The study provides a model to brand management through understanding brand equity building. The projected brand equity map portraying brand awareness, brand loyalty and brand image as causal drivers and perceived quality and brand associations as indirect drivers of brand equity may well be considered as a framework 
Table 2: Descriptive statistics - Brand equity dimensions

\begin{tabular}{|c|c|c|}
\hline \multirow[t]{2}{*}{ Variables } & \multicolumn{2}{|c|}{ Mean \pm Standard deviation } \\
\hline & Beauticians & Consumers \\
\hline Gender & $1.8600 \pm 0.49852$ & $1.6667 \pm 0.49961$ \\
\hline Age & $2.8200 \pm 0.79959$ & $2.5933 \pm 0.96369$ \\
\hline Education & $2.7000 \pm 0.95131$ & $2.7333 \pm 0.99854$ \\
\hline Income & $2.0200 \pm 0.79433$ & $1.7000 \pm 0.73719$ \\
\hline \multicolumn{3}{|l|}{ Brand awareness } \\
\hline Recognize these brands among other brands & $2.2030 \pm 0.67671$ & $2.3057 \pm 0.48104$ \\
\hline Aware of these brands & $1.9576 \pm 0.70143$ & $2.2337 \pm 0.47563$ \\
\hline Characteristics of these brands come to mind quickly & $2.1302 \pm 0.70801$ & $2.3588 \pm 0.51401$ \\
\hline Quickly recall the symbol or logo & $2.0284 \pm 0.63681$ & $2.3019 \pm 0.47631$ \\
\hline Quickly recall the slogan & $2.1562 \pm 0.66490$ & $2.4229 \pm 0.48756$ \\
\hline Quickly recall the commercial jingle & $2.1398 \pm 0.72848$ & $2.3545 \pm 0.50829$ \\
\hline Noticed the signboards & $1.9594 \pm 0.65939$ & $2.2124 \pm 0.51404$ \\
\hline \multicolumn{3}{|l|}{ Perceived quality } \\
\hline Offers good quality services & $2.0106 \pm 0.65153$ & $2.2347 \pm 0.46225$ \\
\hline Offers very reliable services & $2.0452 \pm 0.63028$ & $2.1739 \pm 0.46867$ \\
\hline Quality of services are consistent & $1.9926 \pm 0.60779$ & $2.1998 \pm 0.46157$ \\
\hline Likely quality are extremely high & $2.0580 \pm 0.57751$ & $2.2817 \pm 0.45857$ \\
\hline Utilization convenience & $2.0406 \pm 0.54422$ & $2.2331 \pm 0.49051$ \\
\hline \multicolumn{3}{|l|}{ Brand loyalty } \\
\hline Intention to stay loyal & $2.2178 \pm 0.60025$ & $2.2431 \pm 0.48124$ \\
\hline Recommend to others & $2.2430 \pm 0.60756$ & $2.2904 \pm 0.46016$ \\
\hline First choice for future purchase & $2.3004 \pm 0.63995$ & $2.2439 \pm 0.46192$ \\
\hline Shift to another brand next time & $2.5186 \pm 0.73794$ & $2.4453 \pm 0.47591$ \\
\hline Prefer these brands & $2.2726 \pm 0.62721$ & $2.3361 \pm 0.48760$ \\
\hline Price of these brands & $2.2896 \pm 0.50347$ & $2.2462 \pm 0.39526$ \\
\hline Satisfaction of consumer needs & $2.2344 \pm 0.47621$ & $2.2204 \pm 0.45890$ \\
\hline \multicolumn{3}{|l|}{ Brand association } \\
\hline Trust the company & $1.9534 \pm 0.60618$ & $2.2289 \pm 0.48797$ \\
\hline Like the company & $1.9880 \pm 0.63792$ & $2.3075 \pm 0.48347$ \\
\hline Company really cares about its customers & $1.9838 \pm 0.55675$ & $2.3089 \pm 0.46218$ \\
\hline Honest brand & $1.9558 \pm 0.55188$ & $2.2074 \pm 0.45097$ \\
\hline Offers value for money services & $1.9630 \pm 0.60862$ & $2.2232 \pm 0.46950$ \\
\hline \multicolumn{3}{|l|}{ Brand image } \\
\hline Clean image & $1.9824 \pm 0.60341$ & $2.1876 \pm 0.50624$ \\
\hline Strong image & $2.1326 \pm 0.63282$ & $2.3215 \pm 0.47433$ \\
\hline Overtime they are very consistent in what it stands for & $2.1106 \pm 0.55697$ & $2.3106 \pm 0.46779$ \\
\hline Familiar brand & $2.0224 \pm 0.63375$ & $2.2414 \pm 0.47898$ \\
\hline \multicolumn{3}{|l|}{ Brand equity } \\
\hline Strong brand & $2.2580 \pm 0.50387$ & $2.2211 \pm 0.43594$ \\
\hline Attractive brand & $2.2634 \pm 0.60094$ & $2.2527 \pm 0.46318$ \\
\hline Unique brand & $2.3778 \pm 0.59627$ & $2.2672 \pm 0.47176$ \\
\hline Likable brand & $2.2668 \pm 0.53546$ & $2.2525 \pm 0.46435$ \\
\hline Well-known brand & $2.4660 \pm 0.51632$ & $2.3726 \pm 0.50860$ \\
\hline \multicolumn{3}{|l|}{ Overall scores } \\
\hline Brand awareness score & $2.0866 \pm 0.52339$ & $2.3128 \pm 0.34863$ \\
\hline Perceived quality score & $2.0294 \pm 0.53721$ & $2.2246 \pm 0.35964$ \\
\hline Brand loyalty score & $2.2966 \pm 0.42676$ & $2.2893 \pm 0.30509$ \\
\hline Brand association score & $1.9688 \pm 0.50255$ & $2.2551 \pm 0.35808$ \\
\hline Brand image score & $2.0620 \pm 0.55449$ & $2.2652 \pm 0.39754$ \\
\hline
\end{tabular}

Table 3: Hypothesis testing

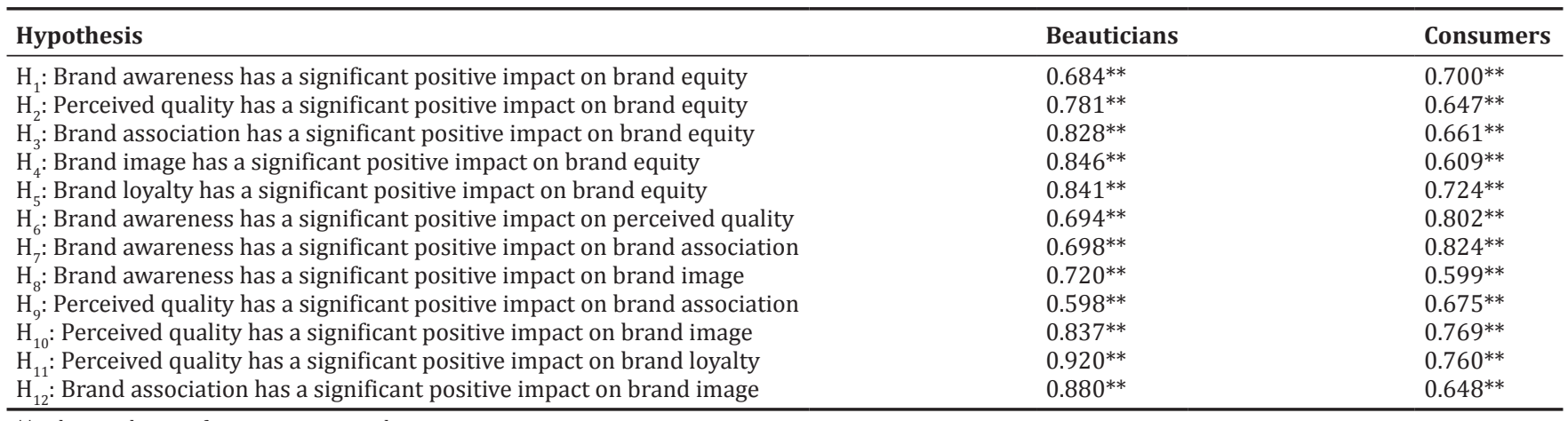

**indicates the significant positive correlation 
Table 4: Intercorrelations - Brand equity dimensions

\begin{tabular}{lllllll}
\hline Type of user & Brand equity & Brand awareness & Perceived quality & Brand loyalty & Brand association & Brand image \\
\hline Beauticians & & & & & \\
$\quad$ Brand equity & 1 & & & & \\
Brand awareness & $0.684^{* *}$ & 1 & 1 & & \\
Perceived quality & $0.781^{* *}$ & $0.674^{* *}$ & $0.920^{* *}$ & 1 & \\
Brand loyalty & $0.828^{* *}$ & $0.698^{* *}$ & $0.598^{* *}$ & $0.874^{* *}$ & 1 \\
Brand association & $0.846^{* *}$ & $0.720^{* *}$ & $0.837^{* *}$ & $0.795^{* *}$ & $0.880^{* *}$ & 1 \\
Brand image & $0.841^{* *}$ & $0.598^{* *}$ & & & \\
Consumers & & & & & \\
Brand equity & 1 & & & & \\
Brand awareness & $0.700^{* *}$ & 1 & 1 & & \\
Perceived quality & $0.647^{* *}$ & $0.802^{* *}$ & $0.760^{* *}$ & & \\
Brand loyalty & $0.661^{* *}$ & $0.676^{* *}$ & $0.675^{* *}$ & $0.789^{* *}$ & 1 \\
Brand association & $0.609^{* *}$ & $0.824^{* *}$ & $0.652^{* *}$ & $0.769^{* *}$ & $0.624^{* *}$ & $0.648^{* *}$ \\
Brand image & $0.724^{* *}$ & & & \\
\hline
\end{tabular}

Table 5: Regression analysis of brand equity components

\begin{tabular}{|c|c|c|c|c|c|}
\hline \multirow{2}{*}{$\begin{array}{l}\text { Brand Equity } \\
\text { Components }\end{array}$} & \multicolumn{2}{|c|}{ Unstandardized coefficients } & \multirow{2}{*}{$\begin{array}{l}\text { Standardized } \\
\text { coefficients }\end{array}$} & \multirow[t]{2}{*}{$\mathbf{t}$} & \multirow[t]{2}{*}{ Significant } \\
\hline & B & Standard error & & & \\
\hline (Constant) & 0.055 & 0.118 & & 0.469 & 0.643 \\
\hline Brand awareness & 0.273 & 0.071 & 0.243 & 3.588 & 0.000 \\
\hline Perceived quality & -0.168 & 0.085 & -0.153 & -1.786 & 0.078 \\
\hline Brand loyalty & 0.510 & 0.096 & 0.411 & 5.217 & 0.000 \\
\hline Brand image & 0.531 & 0.067 & 0.564 & 8.012 & 0.000 \\
\hline
\end{tabular}

${ }^{a}$ Dependent variable: Brand equity

Table 6: Regression analysis - Perceived quality and brand loyalty

\begin{tabular}{|c|c|c|c|c|c|}
\hline \multirow[t]{2}{*}{ Variables } & \multicolumn{2}{|c|}{$\begin{array}{l}\text { Unstandardized } \\
\text { coefficients }\end{array}$} & \multirow{2}{*}{$\begin{array}{l}\text { Standardized } \\
\text { coefficients } \\
\text { Beta }\end{array}$} & \multirow[t]{2}{*}{$\mathbf{t}$} & \multirow[t]{2}{*}{ Significant } \\
\hline & B & $\begin{array}{l}\text { Standard } \\
\text { error }\end{array}$ & & & \\
\hline (Constant) & 0.875 & 0.084 & & 10.426 & 0.000 \\
\hline $\begin{array}{l}\text { Perceived } \\
\text { quality }\end{array}$ & 0.658 & 0.039 & 0.778 & 17.306 & 0.000 \\
\hline
\end{tabular}

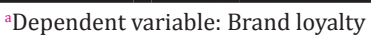

Table 7: Regression analysis - Brand image and brand association

\begin{tabular}{|c|c|c|c|c|c|}
\hline \multirow[t]{2}{*}{ Variables } & \multicolumn{2}{|c|}{$\begin{array}{l}\text { Unstandardized } \\
\text { coefficients }\end{array}$} & \multirow{2}{*}{$\begin{array}{l}\begin{array}{l}\text { Standardized } \\
\text { coefficients }\end{array} \\
\text { Beta }\end{array}$} & \multirow{2}{*}{$\mathbf{t}$} & \multirow[t]{2}{*}{ Significant } \\
\hline & B & $\begin{array}{l}\text { Standard } \\
\text { error }\end{array}$ & & & \\
\hline (Constant) & 0.614 & 0.142 & & 4.375 & 0.000 \\
\hline $\begin{array}{l}\text { Brand } \\
\text { awareness }\end{array}$ & 0.706 & 0.063 & 0.635 & 11.495 & 0.000 \\
\hline
\end{tabular}

${ }^{a}$ Dependent variable: Brand image

for developing brand strategies.

\section{Implications for research}

The influence of brand promotion efforts like company's marketing communications, offers and other price promotions on brand-has not been taken into account, but deserve more research efforts in the future. Similarly, a corporate brand image which is a prominent concept in brand literature and which makes the brand name more identifiable by customers have not been considered in this study. Further research efforts need to assimilate company promotions and the resulting corporate image on individual brand image. Moreover, the study in this paper is limited to a single monolithic brand in the cosmeceutical sector, and hence cannot be generalized.

\section{Summary}

The outcomes of the study confirm that cognitive components of perceived quality and brand association were less contributing to brand equity and the affective component of brand loyalty had stronger underpinning on brand equity construction and hence play an important role in brand management. The brand equity structure gives a very good clarification of brand equity drivers and also their relationships, to formulate a cause and effect model. The model can form a basis for more action-based tactical and operational marketing strategies for other product categories by adding specific questions/items which are particularly important for the individual brands and the company.

\section{REFERENCES}

1. Keller KL. Strategic Brand Management: Building Measuring and Managing Brand Equity. Upper Saddle River, NJ: Prentice-Hall; 1998.

2. Keller KL. Conceptualizing, measuring and managing customer-based brand equity. J Mark 1993;57:1-22.

3. Keller KL. Building and managing corporate brand equity. In: Schultz M, Hatch MJ, Larsen MH, editors. The Expressive Organisation. Linking Identity, Reputation, and the Corporate Brand. Oxford, UK: Oxford University Press; 2000. p. 115-137.

4. Keller KL. Strategic Brand Management. $2^{\text {nd }}$ ed. New Jersey, NJ: Prentice-Hall; 2003.

5. Aaker DA. Measuring brand equity across products and markets. Cal Manag Rev 1996;38(3):102-20.

6. Huang $\mathrm{MH}, \mathrm{Yu}$ S. Are consumers inherently or situationally brand loyal? A set intercorrelation account for conscious brand loyalty and nonconscious inertia. Psychol Mark 1999;16:523-44

7. Yoo B, Donthu N. Developing and validating multidimensional consumer-based brand equity scale. J Bus Res 2001;52(1):1-14.

8. Kim HB, Kim WG. 'The relationship between brand equity and firms' performance in luxury hotels and chain restaurants. Tour Manag 2005;26:549-60.

9. Swait J, Erdem T, Louviere J, Dubelaar C. The equalization price: 
A measure of consumer-perceived brand equity. Int J Res Mark 1993;10:23-45.

10. Van Osselaer S, Janiszewski C. Two ways of learning brand associations. J Consum Res 2001;28:202-23.

11. Reichheld FF. Loyalty-Based Management. Harv Bus Rev 1993;71(2):64-73.

12. Wright C, Sparks L. Loyalty saturation in retailing: Exploring the end of retail loyalty cards? Int J Retail Distrib Management 1999;27(10):429-40.

13. Zeithaml VA, Berry L, Parasuraman A. The behavioral consequences of service quality. J Mark 1996;60:31-46.

14. Srinivasan V, Park CS, Chang DR. An approach to the measurement, analysis and prediction of brand equity and its sources. Manag Sci 2005;51(9):1433-48.

15. Farquhar PH. Managing brand equity. Mark Res 1989;1:24-33.

16. Aaker DA. Managing Brand Equity. New York, NY: The Free Press; 1991.

17. Morgan RP. A customer-oriented framework of brand equity and loyalty. Int J Mark Res 2000;2(3):65-120.

18. Park SU, Srinivasan V. A survey-based method of measuring and understanding brand equity and its extendibility. J Mark Res 1994;31(2):271-88.

19. Kamakura WA, Russell GJ. Measuring brand value with scanner data. Int J Res Mark 1993;10(1):9-22.

20. Cobb-Walgren C, Ruble C, Donthu N. Brand equity, brand preference, and purchase intent. J Adv 1995;24(3):1-9.

21. Sinha A, Pappu R. Parcelling of the sub components of consumer-based brand equity using factorial survey: An empirical investigation in the New Zealand consumer electronics sector. Proceedings, Australia New Zealand Marketing Academy Conference (ANZMAC), University of Otago, Dunedin, December; 1998. p. 2433-8.

22. Yoo B, Donthu N. Testing cross-cultural invariance of the brand equity creation process. J Prod Brand Manag 2002;11(6):380-98.

23. Yoo B, Donthu N, Lee S. An examination of selected marketing mix elements and brand equity. J Acad Mark Sci 2000;28(2):195-211.

24. Washburn JH, Plank RE. Measuring brand equity: An evaluation of a consumer-based brand equity scale. J Mark Theory Pract 2002;10(1):46-62.

25. Konecnik M, Gartner WC. Customer based brand equity for a destination. Ann Tour Res 2007;34(2):400-21.

26. Leone R, Rao V, Keller K, Luo A, Mcalister L, Srivastava R. Linking brand equity to customer equity. J Serv Res 2006;9(2):125-38.

27. Villarejo-Ramos AF, Sanchez-Franco MJ. The impact of marketing communication and price promotion on brand equity. Brand Manag 2005;12(6):431-44.

28. Oliver RL. Whence consumer loyalty. J Mark 1999;63:33-44.

29. Mellens M, Dekimpe MG, Steenkamp EM. A review of brandloyalty measures in marketing. Tijdschrigt voor Economie en Manag 1996;XLI(4):507-33.

30. Van Riel AC, de Mortanges CP, Streukens S. Marketing antecedents of industrial brand equity: An empirical investigation in specialty chemicals. Ind Mark Manag 2005;34(8):841-7.

31. Rios RE, Riquelme HE. Brand equity for online companies. Mark Intell Plann 2008;26(7):719-42. 